\title{
Cyber-Physical System of Psychophysiological Support of Professional Self-Realization in Professions of the 'Man-Nature' Type in the Formation of Specialists for Sustainable Development
}

\author{
Mariia Ruda ${ }^{1, *(\mathbb{D}}$, Oleksandr Moroz ${ }^{2}$, Olha Kuz $^{1}$ and Taras Boyko ${ }^{3}$ \\ 1 Department of Ecological Safety and Nature Protection Activity, Viacheslav Chornovil Institute of \\ Sustainable Development, Lviv Polytechnic National University, 79000 Lviv, Ukraine; olha.n.kuz@lpnu.ua \\ 2 Department of Tourism, Viacheslav Chornovil Institute of Sustainable Development, Lviv Polytechnic \\ National University, 79000 Lviv, Ukraine; olyakuzon@gmail.com \\ 3 Department of Intelligent Mechatronics and Robotics, Institute of Computer Technologies, Automation \\ and Metrology, Lviv Polytechnic National University, 79000 Lviv, Ukraine; tgbo@ukr.net \\ * Correspondence: mariia.v.ruda@lpnu.ua; Tel.: +380-98-79-81-281
}

Citation: Ruda, M.; Moroz, O.; Kuz, O.; Boyko, T. Cyber-Physical System of Psychophysiological Support of Professional Self-Realization in Professions of the 'Man-Nature' Type in the Formation of Specialists for Sustainable Development. Sustainability 2021, 13, 7858. https:/ / doi.org/10.3390/su13147858

Academic Editors: Miltiadis D. Lytras, Abdulrahman Housawi and Basim Alsaywid

Received: 7 May 2021

Accepted: 16 June 2021

Published: 14 July 2021

Publisher's Note: MDPI stays neutral with regard to jurisdictional claims in published maps and institutional affiliations.

Copyright: (c) 2021 by the authors. Licensee MDPI, Basel, Switzerland. This article is an open access article distributed under the terms and conditions of the Creative Commons Attribution (CC BY) license (https:// creativecommons.org/licenses/by/ $4.0 /)$.
Abstract: The article deals with the issue of developing a cyber-physical system of a psychological profile of a specialist in professions of the 'man-nature' type in the formation of specialists for sustainable development. The proposed cyber-physical system of psychophysiological support of professional self-realization in professions of the 'man-nature' type is presented in the form of a hierarchical structure, the upper level of which reflects the vision of the customer (client) and contains the necessary properties and their significance coefficients, and the lower level is a set of characteristics that affect the corresponding properties as well as the corresponding weight values. The cyber-physical system makes it possible to clearly represent the psychophysiological profile of a specialist when working on building a standard of a specialist using the method of expert assessments. This system also allows you to easily automate the process of creating a reference model of a specialist for professions of the 'man-nature' type and will provide estimates of the significance of each of the obtained characteristics. The novelty of the cyber-physical system lies in the integration of points of view on the professional self-realization of a specialist on the part of the customer and on the part of psychologists. The significance of the upper-level elements comes from experts (customers) for each profile, while the weights of the relationship between characteristics and a certain quality are constant regardless of the specialty and can be obtained from expert psychologists in advance. Based on the analysis of a formalized description of available psychodiagnostic techniques, a generalized model of psychodiagnostic techniques and a structural model of a set of psychodiagnostic techniques have been developed. This approach differs from the known ones in a formalized representation, as well as taking into account the vector of resources necessary for the implementation of the technique. The proposed approach made it possible for the first time to formulate the problem of choosing a set of psychodiagnostic techniques as an optimization problem. The developed complex of algorithms, containing all the characteristics of cybernetic systems, is controllable and consists of a set of subsystems that act as mechanisms for the restoration and implementation of self-preserving reactions. That is, this complex of algorithms is effective, which is characterized by a certain set of parameters. Hence, the key role of the system of transmission and processing of information in training specialists for sustainable development becomes clear, and the importance of intellectualization of management processes is explained.

Keywords: psychophysiological standard; professional-defining qualities; specialist professiogram; environmental engineer; employee psychophysiological profile; psychophysiological status; education for sustainable development 


\section{Introduction}

Socio-economic transformations that take place in society are constantly changing the requirements for the personality of a modern specialist. The ability to be the subject of his professional development and independently find solutions to socially and professionally significant problems in a changing reality is becoming increasingly important for him. In addition to professional knowledge and skills, specialists today must also have special abilities, skills, and personality qualities that provide flexibility and dynamism of professional behavior, creativity in professional activities, independence in the search for and processing new information, and gaining professional experience. Of particular importance is the acquisition of the ability to make adequate decisions in 'non-standard» situations, in conditions of time pressure, as well as the development of optimal interaction skills with participants in the production process in joint professional activities. That is why specialists in professions such as the 'man-nature' type need the special attention of scientists. This is due, in addition to the enormous social significance of such professions, which is inherent in them, also to the fact that they are naturally closely integrated into professions of all other types. For example, a filmmaker, an actor (creative professions), a foreman, a workshop manager ('man-engineering'), an environmental worker ('mannature'), a chief accountant, a director of a publishing house ('man-sign'), etc., in addition to their main type of professions, they also refer to professions of the 'man-man' type.

The work features and requirements for specialists in these professions have undergone significant changes over the past 5 years due to the introduction of the concept of sustainable development in Ukraine. A thorough morphological analysis of the concept of 'sustainable development' was carried out in the works of V. Bogolyubov ([1], pp. 28-37), L. Melnyk [2], Yu. Skyba ([3], pp. 95-104) and other researchers [4,5]. At the same time, as can be concluded from the studies of foreign experts D. Wortman [6], D. Tilbury [7], R. McKeown [8], R. Anderson [9], and Ukrainian researchers A.I. Pometun [10], O.Ye. Vysotska [11], V.R. Ilchenko [12], V.Ya. Shvets [13], I.O. Soloshyn [14], S.D. Rudyshyn [15], there is a significant contradiction in the training of specialists of different professions related to the 'man-nature' type: on the one hand, socio-economic changes occurring in society cause increased requirements for such specialists, their activity and responsibility in relation to their own professional and personal development; on the other hand, the training of these specialists is mostly formal, to a large extent. The analysis of literary sources [16-20] shows that most modern definitions of training specialists for sustainable development and education for sustainable development are contextual, formulated in the form of too-broad judgments, and they often lack the generic affiliation of the concept. Psychological-empirical study of the problem by a number of authors [21-25] made it possible to consider professional self-realization as an ability for self-change and as 'self-movement' of a specialist in the space of a profession; as a psychological readiness for constant work on oneself, an active search for opportunities for development; as a human ability, according to L.O. Kalmykova [26], 'to rethink one's own essence', to create oneself and, finally, to achieve the desired effect; as the ability of a person to transform himself-through self-education, self-development, the interiorization of values and norms, etc.-into a full-fledged member of the community of professionals to obtain the outstanding achievements in the profession. In addition, the movement of the individual in the professional space and his achievement of the peak of professional self-realization is determined, according to the study by E.F. Zeyer [27,28] and E.E. Symanyuk [29], by three meaningmaking factors: age-related psychological changes, continuing professional education and the development and transformation of leading activities. These three factors concentrate in themselves both socio-economic conditions and the individual's own mental (socioprofessional) activity, which, according to K. Whitaker [30], is the 'tool' of the profession. However, an analysis of the psychological, pedagogical, and specialized literature indicates that the problem of the formation of the psychophysiological standard of the profession of the 'man-nature' type is not sufficiently reflected in educational research. In this regard, the need for integration of numerous but quite heterogeneous, mixed studies related to various 
aspects of the formation of modern professionals of 'man-nature' type becomes apparent. There is a need to combine purely psychological and psychophysiological aspects of this problem. It is also necessary to develop a holistic system of psychophysiological support for all stages of becoming professionals of this type in training specialists for sustainable development. According to the problem posed, the aim of the study was to develop a cyberphysical system of psychophysiological support for becoming a specialist in professions of the 'man-nature' type in the formation of specialists for sustainable development.

\section{Materials and Methods}

The results presented in the article are based on experimental studies conducted at the V. Chornovil Institute for Sustainable Development (V.Chornovil ISTD) Lviv Polytechnic National University and the laboratory of psychophysiology and occupational health of the State Institution Sanitary and Epidemiological Station on the Lviv Railway of the Ministry of Health of Ukraine. A total of 55 people took part in these studies (40 environmental engineers, former graduates from the V. Chornovil ISTD, and 15 students of the same higher education institution). A total of 546 psychophysiological studies and 789 empirical studies were conducted using the methods described below.

A total of 40 environmental engineers, former graduates from the V. Chernovil ISTD, and 15 students of the same higher education institution were involved in psychophysiological research according to three groups of methods: methods for assessing professionally important psychophysiological qualities-they determine the readiness of the body for emergency action in conditions of monotonously acting factors, reliability of the body in a state of fatigue, attention switching speed, emotional stability, visual and auditory memory. These methods make it possible to determine sensorimotor reactions; methods for assessing the functional state (by means of which you can study the characteristics and psycho-emotional state of the body; methods for studying personality and psychoemotional state) they assess the functional state of the organism: hemodynamic parameters, condition of the cardiovascular system, fatigue of the visual analyzer, state of long-term and short-term memory, reaction to a moving object, state of the nervous system. The study results are presented below.

Also, the participants of the experiment (55 people) were also involved in empirical research using the psychophysiological complex Tolerance, which allows evaluating 10 psychophysiological qualities (this computer system allows you to significantly speed up the testing procedure and preparation of conclusions on professional suitability; it enables to carry out a systematic multi-level examination of operators, to standardize the examination procedure, to objectify test results, to minimize errors and bias in personnel). In addition, the empirical studies were conducted with the help of the Filter technical complex with a set of techniques for assessing professionally important psychophysiological qualities and a functional state; by means of personal computers with a set of necessary techniques for studying personality characteristics and the psychoemotional state of the experimental subjects (MMPI, Raven, Shmishek-Leonhard, Spilberger-Khanin, Lusher). The study results are presented below.

The second stage of the work was the selection of groups of environmental engineers, master's students with relatively high (group A) and relatively low (group B) levels of professional success. Representatives of these groups are typical for the majority of workers/students in this profession by age, professional experience, educational background. Testing was carried out by 21 indicators. To determine the cognitive potential CP (psychophysiological professional suitability), we used methods for assessing 12 professionally important psychophysiological qualities: readiness for emergency actions (REA), reaction to a moving object (RMO), sensorimotor reactions, strength of the nervous system (SNS) mobility of the nervous processes (MNP) attention stability, switching attention, emotional stability, logical thinking, visual memory, long-term memory, and operative memory (shortterm memory). To determine the biological age (BA), methods of assessing the functional 
state were used: the Genchi coefficient, systolic pressure, diastolic pressure, pulse, tilt, the Romberg stance, height, weight.

Professional success (Ekho) was determined by a 10-point system according to other non-psychophysiological criteria, such as learning success (training rating), the absence of accidents, shortcomings in work, violations of labor discipline, the number of vouchers issued, and tourists sent on vacation, etc., the presence of awards or prizes, innovation proposals, initiatives, competence, responsibility, exemplary attitude to their duties, etc.

The practical significance of the study results lies in the wide possibility of their practical use in order to increase the efficiency of professional development of specialists of the 'man-nature' type professions in training specialists for sustainable development in the Baltic Sea region.

The scientific novelty of the work lies in the fact that for the first time, theoretical and methodological principles have been developed for constructing a standard of a profession of the 'man-nature' type.

\section{Results}

The cyber-physical system consists of indicators and four interrelated stages: (1) standardization and weighing; (2) identification of problems and inconsistencies; (3) analysis of effects; and (4) feedback and improvement.

Stage I Standardization and weighing involve comparing the most significant indicators of the four-component structure of the personality model to assess the professional suitability of a specialist.

An integrated approach to assessing the professional suitability of a specialist involves, on the one hand, the study of the profession for which the selection is made, and on the other hand, a psychological study of the personality of the applicants. Therefore, it is advisable to use the method of two profiles as the basis for algorithms and procedures for constructing a standard of a professional worker [31].

The integral profile of a professional worker may consist of various components, according to which professional selection is carried out (intellectual, psychological, psychophysiological, technological, social).

For each component, its own professional defining qualities (PDQs) are determined, their assessment is carried out, and applicants are diagnosed. The professiogram of a specialist of the 'man-nature' type profession can be described using a set of tuples:

$$
\begin{gathered}
\left\langle d_{q_{1}}^{1}, d_{q_{2}}^{1}, \ldots, d_{q_{1}}^{1}\right\rangle,\left\langle d_{q_{1}}^{2}, d_{q_{2}}^{2}, \ldots, d_{q_{u}}^{2}\right\rangle, \\
\left\langle d_{q_{1}}^{3}, d_{q_{2}}^{3}, \ldots, d_{q_{a}}^{3}\right\rangle,\left\langle b_{q_{1}}, b_{q_{2}}, \ldots, b_{q_{k}}\right\rangle, \\
\left\langle t_{q_{1}}, t_{q_{2}}, \ldots, t_{q_{n}}\right\rangle,\left\langle s_{q_{1}}, s_{q_{2}}, \ldots, s_{q_{m}}\right\rangle, \\
\left\langle v_{q_{1}}, v_{q_{2}}, \ldots, v_{q_{r}}\right\rangle,\left\langle z_{q_{1}}, z_{q_{2}}, \ldots, z_{q_{s}}\right\rangle,
\end{gathered}
$$

or by one aggregate tuple:

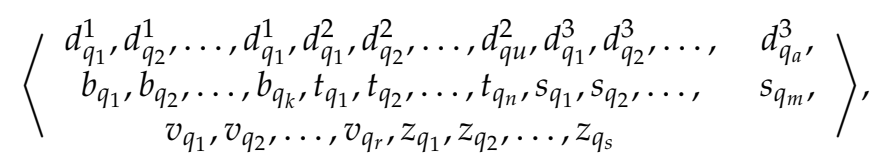

where $D_{1}=\left\{d_{q_{1}}^{1}, d_{q_{2}}^{1}, \ldots, d_{q_{l}}^{1}\right\}$ is a set of requirements imposed on a specialist in a profession of the 'man-nature' type in the field of knowledge; $D_{2}=\left\{d_{q_{1}}^{2}, d_{q_{2}}^{2}, \ldots, d_{q_{u}}^{2}\right\}$ is a set of requirements imposed on a specialist in the field of specialized knowledge; $D_{3}=\left\{d_{q_{1}}^{3}, d_{q_{2}}^{3}, \ldots, d_{q_{a}}^{3}\right\}$ is a set of requirements for intellectual qualities of a specialist; $B=\left\{b_{q_{1}}, b_{q_{2}}, \ldots, b_{q_{k}}\right\}$ is a set of requirements to a specialist to effectively perform the specified functions (psychophysiological requirements); $T=\left\{t_{q_{1}}, t_{q_{2}}, \ldots, t_{q_{n}}\right\}$ is a set of requirements to a specialist in the field of technical training; $S=\left\{s_{q_{1}}, s_{q_{2}}, \ldots, s_{q_{m}}\right\}$ is a set of requirements to a specialist in the field of social relations; $V=\left\{v_{q_{1}}, v_{q_{2}}, \ldots, v_{q_{r}}\right\}$ is a set 
of psychological qualities that a specialist must possess in order to effectively perform the specified functions; $Z=\left\{z_{q_{1}}, z_{q_{2}}, \ldots, z_{q_{s}}\right\}$ is a set of undesirable factors that impede one or another type of professional activities.

Stage II Identification of problems and inconsistencies.

Under real-life conditions, most often, only some of the listed components are subject to consideration. Most commonly, during professional selection, only medical and psychological selections are carried out in stages. Psychophysiological selection and control of professional knowledge are either not carried out at all or are carried out formally.

This division covers the largest set of characteristics that need to be diagnosed. It is the determination of this set of parameters that causes the most significant difficulties. While medical control and the assessment of professional knowledge have legal status, that is, on the basis of the data obtained, an official decision is possible, conducting psychological and psychophysiological selection de jure is not fixed. However, making the correct decision is possible only on the basis of the results of all four components of this process [32].

Currently, the four-component structure of the personality model is widely known [33]:

- Social and professional orientation (inclinations, interests, relations, expectations, mindset, motives);

- professional competence (professional knowledge, abilities, skills, qualifications);

- professionally important qualities (psychological qualities of a personality that determine the productivity of activities-scope, quality, effectiveness, etc.);

- professionally significant physiological qualities (reactivity, energetics, neurotism, extroversion, adaptive tracking, etc.).

The system-forming factor of the personality is their socio-professional orientation, which is characterized by a system of dominant needs and motives. The components of a professional direction are motives, value system, professional approach, and socioprofessional status [34].

Professional competence is often understood as a set of professional knowledge and abilities, as well as ways to perform professional activities. The following main components are distinguished: social and legal competence, specific competence, personal competence, autocompetence, extreme professional competence [35].

In view of this, the specialist's model can be represented in the form of a hierarchical structure (Figure 1), which makes it possible to decompose the qualities of a professional worker using individual characteristics [32].

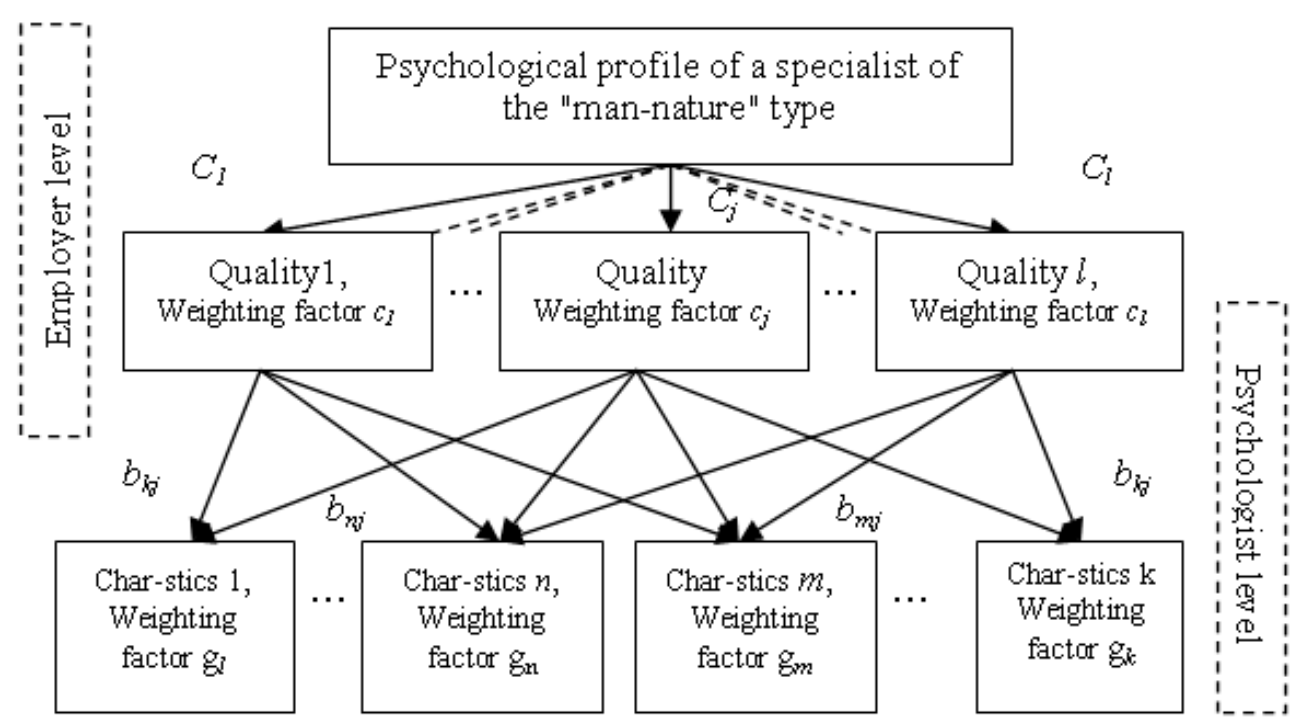

Figure 1. A multi-level model of the psychological profile of a specialist.

The intermediate stage —-theoretically contains the basic theoretical principles of the cyber-physical system: 
- Meaningfully, psychophysiological support of the professional development of a specialist is a system of successive measures aimed at the formation and development of a person's professional orientation and competence, professionally important qualities, and psychophysiological properties in order to achieve a high individually possible professional level and to realize his personal potential in a certain professional activity;

- The course of professional development of a specialist is determined by two groups of factors: external (socio-economic conditions, the content of educational, professional and professional activities, stimulation of career growth, vital events, etc.); internal (biopsychic characteristics, professional activity and motivation, the need for professional self-realization, professional crisis phenomena, etc.);

- The main difficulties and negative phenomena that can hinder the process of professional development are the phenomena of crises of professional development, professional deformations, and 'burnout';

- The subject matter of work in professions of the 'man-nature' type consists in the ability to infer cause-and-effect relationships, analytical thinking, the ability to predict and evaluate the changing factors of the abiotic environment and take into account anthropogenic factors, analysis of the ecosystem as a system (systematic thinking), rich imagination, thinking on feet (operative thinking), observation, endurance, persistence, responsibility, stability, distribution and voluntary switching of attention, visual-figurative, and visual memory;

- Psychophysiological support of the professional development of a specialist should be based on the principles of scientific character, consistency and continuity, optimization, consistency, individualization, adequacy, focus on the maximum possible professional achievements; it can be carried out in four main directions: according to the stages of professional development, according to its components, according to a certain profession and according to the area of activities.

Stage III Analysis of effects.

A psychophysiological profile of a specialist for a profession of the 'man-nature' type can be described as follows: $\left\langle b_{1}, b_{2}, \ldots, b_{l}\right\rangle$ and $\left\langle c_{1}, c_{2}, \ldots, c_{l}\right\rangle$ - for the employer's level; $\left\langle x_{1}, x_{2}, \ldots, x_{k}\right\rangle$ and $\left\langle g_{1}, g_{2}, \ldots, g_{k}\right\rangle$-for the psychologist's level.

In general, the specialist model will take the form:

$$
M=\langle B, C, X, G\rangle .
$$

where $B=\left\{b_{1}, b_{2}, \ldots, b_{l}\right\}$ is a set of qualities that describe the psychophysiological profile of the specialist; $C=\left\{c_{1}, c_{2}, \ldots, c_{l}\right\}$ is a set of weighting factors of qualities; $X=\left\{x_{1}, x_{2}, \ldots, x_{k}\right\}$ are characteristics that describe the whole set $B ; G=\left\{g_{1}, g_{2}, \ldots, g_{k}\right\}$ are corresponding characteristic weighting factors.

The given model makes it possible to demonstrate the psychophysiological profile of a professional worker when constructing a standard psychophysiological profile of a specialist of the 'man-nature' type using the method of expert assessments. It can be used to automate the process of creating a standard of specialty.

One of the main components of professionalization is the determination of the professional suitability of a person for future activities on the basis of his individual psychophysiological qualities. A person's professional activity requires a combination of qualities specific to each individual specialty (intellectual, psychological, psychophysiological characteristics). Their identification, as stated earlier, is one of the greatest difficulties. If the standard is not built correctly, then all further efforts are in vain. Therefore, almost all known methods for solving problems of professional selection are associated with providing this preparatory stage.

In our study, all models, algorithms, and procedures are considered in relation to the psychological and psychophysiological components.

The input data for the appropriate creation of the nomenclature of qualities and the construction of a generalized psychophysiological profile of a specialist is: $\{F\}=\left\{f_{1}, f_{2}, \ldots, f_{l}\right\}$ is a set of functions (specific professional tasks for a specialist of the 'man-nature' type), the 
execution of which is necessary for his successful work. For each function (task), a set of methods is formed for its performance, $\left\{R_{1}\right\}=\left\{r_{11}, r_{12}, \ldots, r_{1 p}\right\},\left\{R_{2}\right\}=\left\{r_{21}, r_{22}, \ldots, r_{2 p}\right\}$, $\ldots,\left\{R_{l}\right\}=\left\{r_{l 1}, r_{l 2}, \ldots, r_{l p}\right\}$.

Using these data as the base, a set of requirements is formed (preliminary), which must be met by a professional worker for the most efficient performance of duties in this specialty. Based on these sets of qualities, a special questionnaire is formed that covers all groups of qualities necessary to build a standard of the 'man-nature' type specialist of a particular specialty.

After this, a survey of experts is conducted $\{E\}=\left\{E_{1}, E_{2}, \ldots, E_{k}\right\}$, who are the most experienced specialists in a specific professional field of activities. Based on these data, the psychophysiological logical standard of a specialist is built (Figure 2).

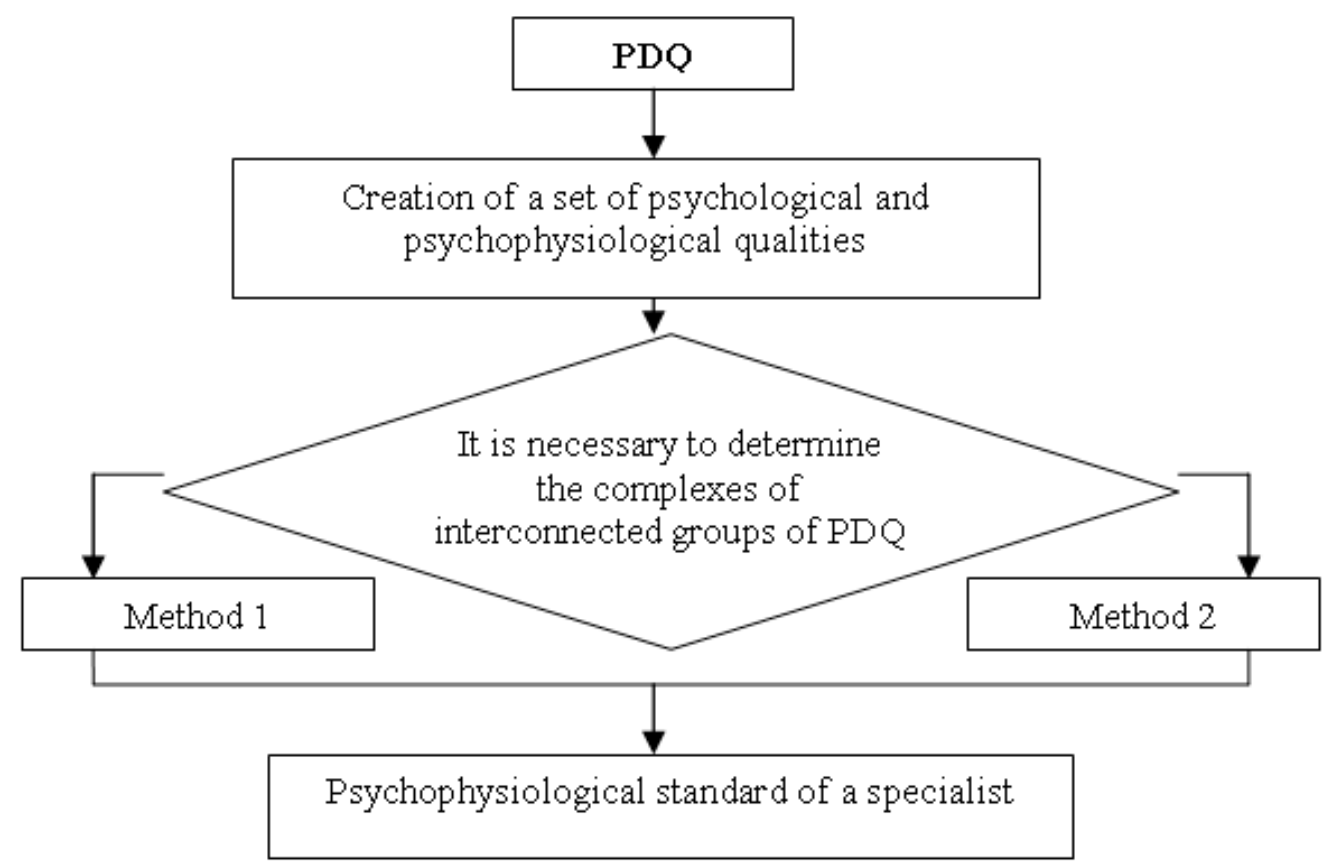

Figure 2. The structure of the method for constructing a generalized psychophysiological profile of a specialist of the 'man-nature' type.

The process of constructing a psychophysiological standard of a professional worker of the 'man-nature' type profession can be implemented using one of two methods [32], the choice of which depends on the required degree of research depth of complexes of interconnected groups of PDQ.

Due to the fact that the activities of a specialist in the 'man-nature' type profession are associated with increased risk and responsibility, it is, therefore, necessary to use a method that involves determining the complexes of interconnected PDQ groups.

Developing a model of the psychophysiological standard of the 'man-nature' type profession is based on the use of the method of expert assessments and factor analysis [36]. The purpose of factor analysis is to determine the relationships between variables (the 'objective R-classification') and the reduction in the number of variables needed to describe the data. Using factor analysis, it is possible to identify hidden variables that are responsible for the presence of linear statistical correlations between the observed variables.

The method for constructing a profile model of the 'man-nature' type profession is described as follows [37]:

1. Forming a list of psychological and psychophysiological qualities. Each $j$-th expert records a number of properties (characteristics) $\Omega_{i}=\left(\omega_{i 1}, \omega_{i 2}, \ldots, \omega_{i l_{i}}\right)$, which, in his opinion, should cover all the necessary characteristics of a specialist of the 'man-nature' type profession. The sets $\Omega_{0}=\bigcap_{i=1}^{k} \Omega_{i}, \Omega_{0}^{1}=\cup_{i=1}^{k} \Omega_{i}, \Omega_{0}^{11}=\Omega_{0}^{1} \backslash \Omega_{0}$ are formed and analyzed. 
It should be borne in mind that $\Omega_{0}$ is the set of necessary qualities (characteristics) and $\Omega_{0}^{11}$ is the set of the desired qualities.

2. Each of the experts $E j,(j=1,2, \ldots k)$ puts for each element of the set their coefficients of significance in the range from -3 to +3 , forming the vector $\vec{a}_{j}=\left(a_{j 1}, a_{j 2}, \ldots a_{j N}\right)$ from those considerations that will reveal along with the positive qualities that increase work efficiency, also negative ones that reduce the efficiency of the specialist.

3. Having been received from the experts, the estimates are normalized by the Formula (4):

$$
a^{\prime}{ }_{j i}=\frac{a_{j i}}{\sum_{i=1}^{N} a_{j i}}
$$

where $j=1,2, \ldots k, i=1,2, \ldots N$ in order for the relationship $\sum_{i=1}^{N} a^{\prime} j i=1, j=1,2, \ldots, k$ to be fulfilled, as a result of which we obtain a matrix:

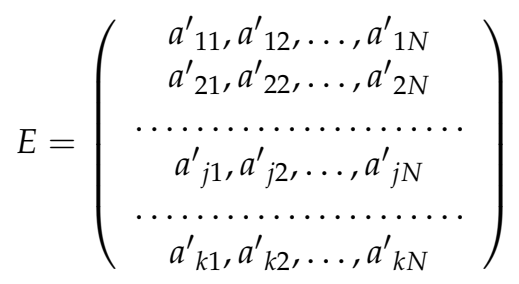

where $N$ is the number of psychological and psychophysiological qualities, and $k$ is the number of experts.

4. After constructing the matrix $E$, the consistency of experts' judgments is checked.

To assess the consistency, it is proposed to use simple and user-friendly criteria that take into account the opinions of experts:

- The maximum ratio of half the scatter of indicators to the arithmetic mean:

$$
\Delta_{i}=\max _{j} \frac{\beta_{j}\left|a_{{ }^{\prime}}{ }_{j i}-\overline{a^{\prime}}{ }_{i}\right|}{2 \overline{a^{\prime}}{ }_{i}}, i l=1,2, \ldots, k,
$$

where $\beta_{j}$ is the coefficient of competence of the $j$-th expert;

- Relative deviation of the arithmetic mean from the geometric mean:

$$
\Delta_{2 i}=1-\frac{c_{g i}}{c_{h i}}, i=1,2, \ldots, k,
$$

where $c_{h i}$-arithmetic mean; $c_{g i}$ the geometric mean value is calculated by the following Formula (8):

$$
c_{i}=\sum_{j=1}^{k} \beta_{j} \sqrt{\prod_{j=1}^{k} a^{\prime} \beta_{j i}}=\exp \left(\frac{\sum_{j=1}^{k} \beta_{j} \ln a^{\prime}{ }_{j i}}{\sum_{j=1}^{k} \beta_{j}}\right) .
$$

If the opinions of the experts are not agreed, there is a transition to paragraph 2. If they are not agreed a second time, it is recommended that the expert group be disbanded and re-created. The consistency of experts' judgments is determined by the Formulas (5)-(8).

5 . Using the Hadamard product of the matrix $E$ by the matrix of expert competence coefficients for a certain group of qualities, we obtain the matrix:

$$
E^{\prime}=E \cdot D .
$$


where matrix $D$ is the matrix of expert competence coefficients formed from the following considerations. For each $j$-th expert who participates in the professional selection, a set of competence coefficients is formed:

$$
d_{j}=\left\{d_{j 1}, d_{j 2}, \ldots, d_{j k}, \ldots, d_{j h_{j}}\right\}
$$

where $d_{j h_{j}}$ is the competence coefficient of the $j$-th expert in the $h_{j}$-th group of psychological and psychophysiological qualities (characteristics).

$$
\underbrace{b_{1} \ldots b_{g} b_{j} \ldots b_{l}}_{d_{i 1}} \ldots \underbrace{b_{h} \ldots b_{N}}_{d_{i k}}
$$

where $b_{j} \ldots b_{l}$ is a group of psychological and psychophysiological qualities of the 'mannature' type professions.

This division of competences is due to the assumption that the experts may not have the same competence in all professions of the 'man-nature' type.

6. Using factor analysis, namely, the principal-factor method [38], to highlight the key factors and cut off the least significant, we can leave only the qualities that are really significant for a given specialty (position).

Intermediate stage quantitative-empirical suggests that psychophysiological support of professional development should be based on the results of empirical research aimed at quantitative-empirical concretization of psychological and psychophysiological characteristics and factors of the professional development of a specialist in professions of this type; in particular, the developed methodological and practical aspects of such support are based on empirical results obtained during the study on the professional orientation, competence and motivation of specialists, their characterological, neurodynamic, temperamental and emotional properties, myokinetic abilities, peculiarities of thinking, imagination, attention, emotional sphere and self-regulation.

In this study, we aimed to select the best methods for diagnosing PDQ and build a psychophysiological standard of the 'man-nature' type profession, that is, to determine the necessary level of PDQ development and the boundaries of permissible deviations of the level of development of psychophysiological qualities in real profiles of an employee (RPE) or an applicant.

The first step is the selection of methods for studying professionally important qualities of the 'man-nature' type profession, which would ensure adequate assessment with sufficient reliability [39]. To build the correct model, it was necessary to make a number of refinements and explanations. Thus, the general characteristics of the 'man-nature' type professions are as follows:

- Means and objects of production of the 'man-nature' type profession are objects of living and abiotic nature, as well as anthropogenic and biological processes;

- Main activities-study, research, analysis, design, extraction, cultivation, care, prevention;

- The main requirements of the profession to the employee are: the ability to establish cause-and-effect relationships, analytical thinking, the ability to predict and assess the changing factors of the abiotic environment and take into account anthropogenic factors, analysis of the ecosystem as a system (systemic thinking), rich imagination, operational thinking, observation, endurance, persistency, responsibility, steadiness of mind, distribution and random switching of attention, visual-imagery, and visual memory;

- Professional activities of various workers of the 'man-nature' type professions require the use of a wide range of knowledge and intellectual skills from automation of processes and knowledge of the technological cycle of production to knowledge of the laws of growth and development of living organisms and biotopes, at the same time, significant changes in the nature and content of the professions of the 'man-nature' group requires the development of rational methods for conducting career-oriented 
and vocational counseling work with school students, taking into account the specifics of these changes;

- Objects of labor are: climatope, edaphotope, hydrotope, as well as biocoenoses of different taxonomic rank;

- The tools of specialists of the 'man-nature' type professions are very diverse and heterogeneous. They can be classified as follows: hand tools and fixtures; mechanical tools and devices; machines with manual and automatic control; devices designed to detect signs that are not directly perceived by the senses.

- The working conditions for specialists of this type of profession may be the most diverse: daytime work, shift working; night work, shift working; irregular (long) working hours; work with the predominance of static components in actions (prolonged stay in one working position: sitting, standing); work that requires movement;

- For the professions of the 'man-nature' group, the preferred activities that have informational features are as follows: observation, control as gnostic actions (observation, measuring, inspection, examination by touch, taste test), solving operational and production tasks and other mental actions (planning, experimenting), processing of materials (processing, sorting, stacking, monitoring, measuring), control of mechanisms, machines, maintenance and care (for equipment, animals, plants), organization of a team and education of people;

- $\quad$ Based on working conditions, for professions of the 'man-nature' type, the following occupational hazards can be identified: overheating/hypothermia of the body, exposure to chemicals or toxic substances, stress, and work in conditions of uncertainty.

Group A included 20 professionally successful workers, environmental engineersgraduates from the V. Chernovil ISTD, with indicators of professional success being from 8 to 10 points. In addition, five master's students were in this group, with indicators of education quality being from 9 to 10 points.

Group B included 20 employees who have little work experience or just learning the profession of environmental engineer. They are graduates from the V. Chernovil ISTD whose activities success is beyond doubt by the same criteria, with indicators of professional success being from 0 to 4 points. This group also included 10 students, whose indicators of education quality are from 5 to 7 points.

We found the optimal level of PDQ development by constructing the averaged profiles of environmental engineers of both groups. The next step was to find common arithmetic means that meet the criteria of optimal psychophysiological readiness (OPR) for the profession of environmental engineer (Table 1).

Table 1. Dependence of professional success on neurodynamic qualities of environmental engineers (fragment of the table).

\begin{tabular}{|c|c|c|c|c|c|c|c|c|c|}
\hline $\begin{array}{l}\text { Belonging to } \\
\text { the Study } \\
\text { Group }\end{array}$ & $\begin{array}{l}\text { Item No. of } \\
\text { the Study } \\
\text { Subject }\end{array}$ & $\begin{array}{l}\text { Year of } \\
\text { Birth }\end{array}$ & $\begin{array}{l}\text { Age from } \\
\text { Birth } \\
\text { Certificate }\end{array}$ & $\begin{array}{l}\text { Physiological } \\
\text { Age }\end{array}$ & Rnp-1 & Cnc & $\begin{array}{l}\text { Cognitive } \\
\text { Potential }\end{array}$ & $\begin{array}{l}\text { Professional } \\
\text { Success }\end{array}$ & $\begin{array}{l}\text { Cognitive } \\
\text { Potential }\end{array}$ \\
\hline \multirow{10}{*}{ Group A } & 1 & 1984 & 35 & 32 & 8.6 & 121 & 200.00 & 10 & 8 \\
\hline & 2 & 1985 & 34 & 30 & 10.6 & 108 & 199.00 & 8 & 7 \\
\hline & 3 & 1985 & 34 & 31 & 12 & 71 & 239.00 & 7 & 6 \\
\hline & 4 & 1986 & 33 & 32 & 9.2 & 96 & 244.00 & 8 & 7 \\
\hline & 5 & 1984 & 35 & 32 & 2 & 92 & 198.00 & 10 & 8 \\
\hline & 21 & 1999 & 20 & 18 & 7.6 & 92 & 199.00 & 10 & 8 \\
\hline & 22 & 1999 & 20 & 19 & 14.6 & 83 & 196.00 & 8 & 7 \\
\hline & 23 & 1998 & 21 & 18 & 9.3 & 99 & 309.00 & 6 & 6 \\
\hline & 24 & 1999 & 20 & 18 & 14.2 & 89 & 201.00 & 9 & 8 \\
\hline & 25 & 1998 & 21 & 18 & 15 & 72 & 344.00 & 5 & 4 \\
\hline
\end{tabular}


Table 1. Cont.

\begin{tabular}{|c|c|c|c|c|c|c|c|c|c|}
\hline $\begin{array}{l}\text { Belonging to } \\
\text { the Study } \\
\text { Group }\end{array}$ & $\begin{array}{l}\text { Item No. of } \\
\text { the Study } \\
\text { Subject }\end{array}$ & $\begin{array}{l}\text { Year of } \\
\text { Birth }\end{array}$ & $\begin{array}{l}\text { Age from } \\
\text { Birth } \\
\text { Certificate }\end{array}$ & $\begin{array}{l}\text { Physiological } \\
\text { Age }\end{array}$ & Rnp-1 & Cnc & $\begin{array}{l}\text { Cognitive } \\
\text { Potential }\end{array}$ & $\begin{array}{l}\text { Professional } \\
\text { Success }\end{array}$ & $\begin{array}{l}\text { Cognitive } \\
\text { Potential }\end{array}$ \\
\hline \multirow{9}{*}{ Group B } & 26 & 1989 & 30 & 32 & 18.1 & 74 & 305.00 & 5 & 4 \\
\hline & 27 & 1987 & 32 & 35 & 16.8 & 82 & 303.00 & 6 & 5 \\
\hline & 28 & 1990 & 29 & 32 & 13.1 & 102 & 212.00 & 8 & 7 \\
\hline & 29 & 1987 & 32 & 32 & 8.9 & 128 & 216.00 & 8 & 8 \\
\hline & 46 & 1999 & 20 & 22 & 9.9 & 89 & 211.00 & 8 & 7 \\
\hline & 47 & 1999 & 20 & 23 & 22.6 & 114 & 201.00 & 9 & 5 \\
\hline & 48 & 1998 & 21 & 23 & 7.6 & 122 & 198.00 & 10 & 9 \\
\hline & 49 & 1998 & 21 & 22 & 8.2 & 96 & 213.00 & 9 & 8 \\
\hline & 50 & 1999 & 20 & 23 & 18.1 & 86 & 324.00 & 6 & 4 \\
\hline
\end{tabular}

Thus, optimal psychophysiological readiness OPR acquires a quantitative characteristic and allows us to compare profiles, real and standard, which makes it possible to determine the degree of applicants' suitability (DAS), using the level of profile adequacy as criteria.

After statistical processing of test results, the following was found:

- The coefficient of correlation of the readiness for emergency actions (REA) with professional success is 0.9 .

Let us estimate the correlation density by calculating the Pearson correlation coefficient $\bar{r}=0.9$, according to the Chaddock table. The coefficient of correlation of the readiness for emergency actions (REA) with professional success is very high. Considering ${ }^{-2}=0.81$, then REA is $81 \%$ dependent on professional success and $19 \%$ on other factors. For the significance level $\alpha=0.05$, we check the null hypothesis $H_{0}: r=0$ according to the competing hypothesis $H_{1}: r \neq 0$. We calculate the empirical value of the criterion: $T_{e m p}=\bar{r} \frac{\sqrt{n-2}}{1-r}=0.9 \frac{\sqrt{55-2}}{\sqrt{1-0.9}}=16.365$.

For a given level of significance and the number of degrees of freedom $k=55-2=53$ by using the table of critical points of Student's distribution, we find that $t_{k r}=1.96$. Since $T_{e m p}>t_{k r}$, we reject the null hypothesis $H_{0}$ and conclude that the sample correlation coefficient is significant and random variables are correlated. We calculate the confidence interval for the general correlation coefficient: $\bar{r}-t_{k r} \frac{1-r}{\sqrt{n}} \leq r \leq \bar{r}+t_{k r} \frac{1-r}{\sqrt{n}}$.

$$
0.9-0.05 \leq r \leq 0.9+0.05
$$

- The coefficient of correlation of the reaction to a moving object (RMO) with professional success is 0.7 . The confidence interval for the general correlation coefficient: $0.7-0.13 \leq r \leq 0.7+0.13$;

- The coefficient of sensorimotor reactions correlation with professional success is 0.9 . The confidence interval for the general correlation coefficient: $0.9-0.05 \leq r \leq 0.9+0.05$;

- The coefficient of the strength of nervous system (SNS) correlation with professional success is 0.6 . The confidence interval for the general correlation coefficient: $0.6-0.17 \leq r \leq 0.6+0.17$

- The coefficient of the mobility of nervous processes (MNP) correlation with professional success is 0.6 . The confidence interval for the general correlation coefficient: $0.6-0.17 \leq r \leq 0.6+0.17$

- The coefficient of the emotional stability (robustness) and switching attention (refocusing) correlation with professional success is 0.9 . The confidence interval for the general correlation coefficient: $0.9-0.05 \leq r \leq 0.9+0.05$;

- The coefficient of logical thinking correlation with professional success is 0.77 . The confidence interval for the general correlation coefficient: $0.77-0.11 \leq r \leq 0.77+0.11$; 
- The coefficient of visual memory correlation with professional success is 0.6. The confidence interval for the general correlation coefficient: $0.6-0.17 \leq r \leq 0.6+0.17$;

- The coefficient of long-term memory correlation with professional success is 0.3 . The confidence interval for the general correlation coefficient: $0.3-0.2 \leq r \leq 0.3+0.2$;

- The coefficient of short-term (operative) memory correlation with professional success is 0.2 . The selective correlation coefficient is insignificant and random values are uncorrelated.

Comparison of several profiles allows us to see the excess of the optimal level of PDQ development in DAS over the requirements of OPR, which also, in some cases, is a signal that the employee has 'outgrown' his profession, which means that his interest in work and the level of motivation are reduced, and this in certain situations lead to a malfunction.

A differential diagnostic scale has been developed for assessing the results of psychophysiological examinations using a standardized indicator that divides the normal distribution of PDQ measurements into 10 points on a one-dimensional ranking scale from the lowest value equal to 1 point to the highest one, which is 10 points (each point is a certain part in \% of a representative sample of the examined environmental engineers. The 'raw' indicator obtained during the examination is translated into normalized scores, which makes it possible to compare the results of the examination of various groups of workers-to develop uniform criteria for assessing optimal readiness for a profession.

Based on the data obtained, a histogram of factor values of the performance efficacy of environmental engineers was constructed, where, in addition to factor values, the possibility of mastering the profession of the environmental engineer was taken into account.

Thus, professional defining qualities (PDQ) for environmental engineers can be considered: psychomotor qualities (readiness for emergency action (REA)), neurodynamic qualities (sensorimotor reactions), and sensory-perceptual qualities (emotional stability and switching of attention). The least pronounced is the dependence of professional success on the mnemonic qualities of environmental engineers of the two groups.

No reliable relationship has been established: between professional success and biological age as well as age from birth certificate; between cognitive potential and biological and age from a birth certificate. This can be explained by compensation for the deterioration of physiological and psychophysiological indicators with age due to the high level of professionalism and motivation of the employee. The correlation coefficient of professional success (Ekho) and calculated cognitive potential (CP) is 0.87 .

The results of psychophysiological examinations indicate that the construction of the psychophysiological standard of the profession with sufficient probability predicts the success and reliability of the work of employees and makes it possible to identify contraindications to professional activities.

Obviously, the value (see Formula (6)) should be small (with satisfactory consistency of the expert judgments) for sufficiently significant indicators. Testing this ratio on the experimental results showed that the $\Delta_{i}$ value increases sharply for insignificant indicators. As a result, we obtain a series of significance coefficients of qualities $\{X\}$ that determine the standard of a professional worker's profile.

The flowchart of the method for constructing the psychophysiological standard of the 'man-nature' type profession is presented in Figure 3. 


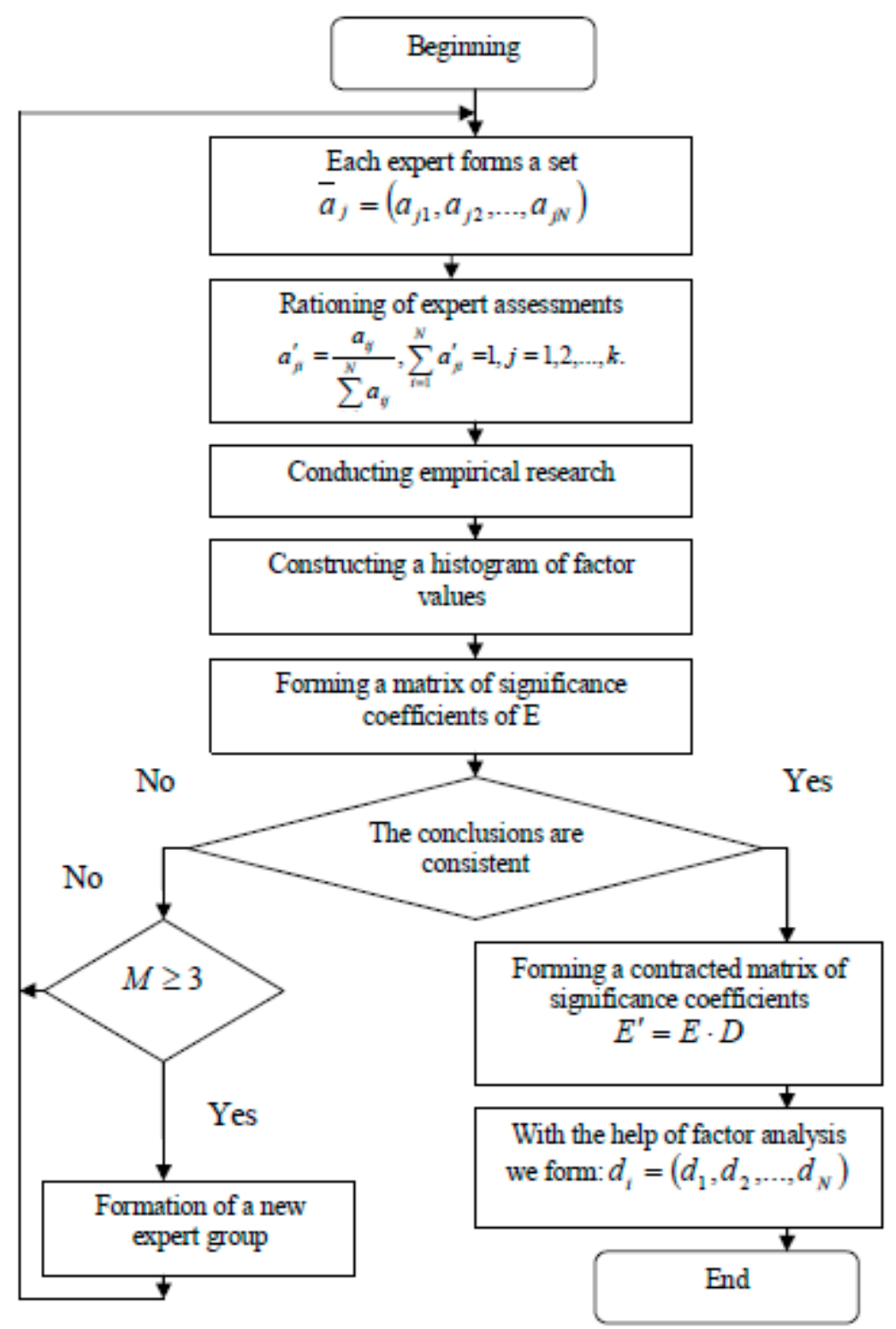

Figure 3. The method of constructing a psychophysiological standard of the 'man-nature' type specialist.

Using the matrix of expert competence coefficients for certain groups of qualities allows improving the quality of the constructed standard model. In addition, the use of factor analysis makes it possible to identify hidden relationships between qualities, which will allow us to monitor complexes of interrelated PDQ groups in the diagnosis of the 'man-nature' type profession to increase the reliability of the results of the professional selection procedure.

Thus, the formalization of the structure of professional selection makes it possible to more clearly represent and formulate requirements for the basic models and procedures used at various stages of professional selection.

Stage IV Feedback and improvement provides a list of key activities aimed at developing and further practical use of the cyber-physical system: determination of the general content, components, and factors of professional development of the specialist; as well as the need for continuous research aimed at tracking changes in psychological and psychophysiological aspects of professional activity in professions of the 'man-nature' type, appropriate consideration of these changes in the activities, obtaining information on the effectiveness of activities to improve them and train professionals for sustainable development.

The developed cyber-physical system contains all the characteristics of cybernetic systems-it is controllable, consists of a complex of subsystems that act as mechanisms for 
working out and implementing self-preserving reactions. That is, it is effective, characterized by a certain set of parameters. This explains the key role of the system of transmission and processing of information in training specialists for sustainable development, as well as the importance of intellectualization of management processes.

\section{Discussion}

The theoretical and empirical results obtained during the research provided an opportunity to formulate and substantiate the cyberphysical system of psychophysiological support for becoming a specialist in professions of the 'man-nature' type in the formation of specialists for sustainable development. A similar approach was first used by the authors. The works [39-42] are described as the automation of the decision-making process in the implementation of vocational guidance work. Professions of the 'man-nature' type make up a fairly large group. This includes professions that require significant theoretical training, and hence, higher and secondary specialized education (environmental engineer, agronomist, veterinarian, veterinary technologist, zootechnician, gardener, landscape architect, etc.), and professions that require practical skills, the foundations of which are laid, for example, in a vocational school (livestock breeder, tractor driver of general profile, master of machine milking). Thus, there is a need to study these professions, drawing up professiograms and using them in the organization of practical career guidance work. These professions need special attention because, firstly, they are common in agriculture, which is an important sector of the national economy. Secondly, there is a shortage of qualified professionals. Thirdly, the requirements for the psycho-physiological characteristics of workers are very important, and their decoding is of considerable interest for the practice of career guidance and vocational counseling of school youth [43-45].

\section{Conclusions}

According to the purpose of the study, the authors have integrated numerous, but rather heterogeneous, mixed studies related to various aspects of the formation of modern specialists of the 'man-nature' type. The authors have implemented a combination of purely psychological and psychophysiological aspects of this problem. An integral system of psychophysiological support has been developed for all stages of the formation of professionals of the 'man-nature' type to train specialists for sustainable development. The model built by the authors of the psychophysiological profile of a specialist is presented in the form of a hierarchical structure, the upper level of which reflects the employer's vision and contains the necessary qualities and their significance coefficients. The lower level of the structure is a set of characteristics that affect the corresponding qualities and the corresponding weight values.

This model of a psychophysiological profile of a specialist in the 'man-nature' type profession allows you to visualize this profile when working on building a specialist's standard using the method of expert assessment and allows you to easily automate the process of creating the standard model of a professional worker for the 'man-nature' type profession, as well as to obtain estimates of the significance of each of the professional characteristics. The novelty of the proposed cyberphysical system lies in the integration of points of view on the standard of a specialist on the part of customers (employers) and on the part of psychologists, in this case, the significance of the top-level elements comes from the expert customers for each profile of a professional worker, while the weights of the relationship between characteristics and certain qualities can be obtained from expert psychologists in advance. A comprehensive assessment of the professional characteristics of a specialist of the 'man-nature' type is formed using methods of hierarchy analysis, taking into account the significance (weights) of experts. Thus, the use of the cyberphysical system proposed by the authors for psychophysiological support of professional self-realization in professions of the 'man-nature' type in the formation of specialists for sustainable development will allow in the future to formalize the structure of professional selection. In the future, developing this approach will make it possible to more clearly represent and 
formulate the requirements for the basic models and procedures used at various stages of the professional selection of workers.

Author Contributions: Conceptualization, M.R.; methodology, M.R. and T.B.; software, M.R. and T.B.; validation, O.M.; formal analysis, O.K. and T.B.; investigation, O.M. and O.K.; resources, M.R. and O.K.; data curation, T.B.; writing—original draft preparation, M.R.; writing—review and editing, O.K.; visualization, M.R. and T.B; supervision, O.M; project administration, O.K. All authors have read and agreed to the published version of the manuscript.

Funding: This research received no external funding.

Institutional Review Board Statement: The study was conducted according to the guidelines of the Declaration of Helsinki, and approved by the Institutional Review Board of VIACHESLAV CHORNOVIL INSTITUTE OF SUSTAinABLE DEVELOPMENT (protocol code 2 of 17 November 2020).

Informed Consent Statement: Informed consent was obtained from all subjects involved in the study.

Conflicts of Interest: The authors declare no conflict of interest.

\section{References}

1. Boholiubov, V.M. Stalyi Rozvytok Suspilstva: Sotsialno-Ekolohichni Aspekty Formuvannia Profesiinoi Kompetentnosti Mahistriv-Ekolohiv [Sustainable Development of Society: Socio-Ecological Aspects of the Formation of Professional Competence of Masters of Ecology]; Hrin: Kherson, Ukraine, 2013. (In Ukrainian)

2. Melnyk, L.H. Fundamentalnые OsnovыUstoichyvoho Razvytyia [Fundamentals of Sustainable Development]; Unyversytetskaia Knyha: Sumy, Ukraine, 2003. (In Russian)

3. Skyba, Y.A. Formuvannia Upravlinskykh Kompetentsii Maibutnikh Ekolohiv na zasadakh Zbalansovanoho Rozvytku: Teoriia ta Praktyka: Monohrafiia [Formation of Managerial Competencies of Future Ecologists on the Basis of Balanced Development: Theory and Practice: Monograph]; NPU Imeni M.P. Drahomanova: Kyiv, Ukraine, 2013. (In Ukrainian)

4. Mitcham, C. The concept of sustainable development: Its origins and ambivalence. Technol. Soc. 1995, 17, 311-326. [CrossRef]

5. Klarin, T. The Concept of Sustainable Development: From its Beginning to the Contemporary Issues. Int. Rev. Econ. Bus. 2018, 21, 67-94. [CrossRef]

6. Pometun, O.I. Pedahohichni zasady osvity dlia staloho rozvytku v Ukrainskii shkoli [Pedagogical principles of education for sustainable development in the Ukrainian school]. Ukr. Pedahohichnyi Zhurnal 2015, 1, 171-182. (In Ukrainian)

7. Tilbury, D.; Wortman, D. Enganging People in Sustainability; IUCN: Gland, Switzerland, 2004.

8. McKeown, R. Education for Sustainable Development Toolkit; Printed in UNESCO's Workshop: Paris, France, 2006.

9. Andersone, R. The Content Reform of Education for Sustainable Development. In Proceedings of the Rural Environment. Education. Personality. International Scientific Conference, Jelgava, Latvia, 15-16 May 2015; pp. 75-81.

10. Pometun, O.I. Pidhotovka Vchyteliv do Vykladannia Pytan Staloho Rozvytku. Navchalno-Metodychni Materialy dlia Vykladachiv Vyshchykh Pedahohichnykh Navchalnykh Zakladiv ta Systemy Pisliadyplomnoi Pedahohichnoi Osvity [Teacher Training for Teaching Sustainable Development Issues. Educational and Methodical Materials for Teachers of Higher Pedagogical Educational Institutions and the System of Postgraduate Pedagogical Education]; Pedahohichna Dumka: Kyiv, Ukraine, 2015. (In Ukrainian)

11. Vysotska, O. Osvita dlia Staloho Rozvytku [Education for Sustainable Development]; Roial Prynt Dnipropetrovsk: Dnipropetrovsk, Ukraine, 2011. (In Ukrainian)

12. Ilchenko, V.R. Modernizatsiia Zmistu Zahalnoi Serednoi Osvity Ukrainy na Zasadakh Osvity dlia Staloho Rozvytku: Nacherk Proektu Eksperymentalnoho Doslidzhennia [Modernization of the Content of General Secondary Education in Ukraine on the Basis of Education for Sustainable Development: An outline of a Pilot Study Project]. Postmetodyka 2011, 5, 16-17. (In Ukrainian)

13. Shvets, V.Y.; Palekhova, L.L.; Shmidt, M.; Palekhov, D.A. Partnerstvo kak metod prodvyzhenyia modely vыssheho obrazovanyia dlia tselei ustoichyvoho razvytyia [Partnership as a Method to Promote a Higher Education Model for Sustainable Development]. Rozvyt. Ekon. Osv. 2015, 3, 146-154. (In Russian)

14. Soloshych, I.O.; Pidlisniuk, V.V. Doslidzhennia obiznanosti ideiamy staloho rozvytku suspilstva v konteksti ekolohichnykh problem [Research of awareness of the ideas of sustainable development of society in the context of environmental problems]. Vypusk 2011, 3, 155-158. (In Ukrainian)

15. Rudyshyn, S.; Koreneva, I. Development of Unsversity Students' Ability to Undestad the World Scientific Pattern. Adv. Sci. J. US 2014, 5, 7-12. [CrossRef]

16. Azizov, A.A.; Akinshina, N.G. Obrazovanie v Interesah Ustojchivogo Razvitija: Uchebno-Metodicheskoe Posobie [Education for Sustainable Development: Study Guide]; NESKO: Tasheknt, Uzbekistan, 2016. (In Russian)

17. Isaienko, V.M. Stratehichne bachennia innovatsiinoi roli osvity dlia staloho rozvytku Ukrainy [Strategic vision of the innovative role of education for sustainable development of Ukraine], Stratehiia staloho rozvytku Ukrainy: Zavdannia osvity shchodo yii realizatsii: Materialy III Vseukrainskoho forumu "Osita dlia zbalansovanoho rozvytku". In Proceedings of the Tsentr Ekolohichnoi Osvity ta Informatsii, Kyiv, Ukraine, 12-13 April 2017; pp. 8-10. (In Ukrainian) 
18. Marfenin, N.N. Osnovnye Problemy i Zadachi Obrazovanija dlja Ustojchivogo Razvitija [The Main problems and Tasks of Education for Sustainable Development]; Jagodina, G.A., Ed.; Centr «Shkol'naja Kniga»: Moscow, Russia, 2009; pp. 9-31. (In Russian)

19. Campbell, J.S.; Castaneda, M.; Pulos, S. Meta-analysis of personality assessments as predictors of militaryaviation training success. Int. J. Aviat. Psychol. 2009, 1, 92-109. [CrossRef]

20. Kal'nish, V.V.; Ena, A.M. Sovremennoe sostoyanie professional'nogo psihofiziologicheskogo otbora vUkraine [The current state of professional psychophysiological selection in Ukraine]. Occup. Med. Ind. Ecol. 2006, 3, 12-17. (In Ukrainian) [CrossRef]

21. Ancyferova, L.I. Razvitie Lichnosti Specialista kak Subekta Svoej Professional'noj Zhizni [Development of the Personality of a Specialist as a Subject of His Professional Life], Psihologicheskie Osnovy Professional'noj Dejatel'; PER SJe; Logos: Moskva, Russia, 2007 ; pp. 499-507. (In Russian)

22. Gulyas, I.A. Determinanty` Samozdijsnennya Osoby'Stosti [Determinants of personality self-realization]. Pedagog. Proces: Teor. Prakty'ka 2011, 17, 83-92. (In Ukrainian)

23. Dubchak, G.M. Psy'Xologichni Osnovy' Profesijnoyi Stresostijkosti Majbutnix Faxivciv [Psychological Bases of Professional Stress Resistance of Future Specialists]; Talkom: Kyiv, Ukraine, 2017. (In Ukrainian)

24. Kokun, O.M. Psy'xologiya Profesijnogo Stanovlennya Suchasnogo Faxivcya [Psychology of Professional Development of a Modern Specialist]; Inform.-analit. agenstvo: Kiev, Ukraine, 2012. (In Ukrainian)

25. Korniyenko, I.O. Psy'Xologiya Opanuval'Noyi Povedinky' Osoby'Stosti: Monografiya [Psychology of Mastering Personality Behavior: A Monograph]; RVU MDU: Mukachevo, Ukraine, 2017. (In Ukrainian)

26. Kalmy'kovoyi, L.O.; Xomy'ch, G.O. Rozvy'tok Osoby'Stosti v Rizny'x Umovax Socializaciyi: Kolekty'vna Monografiya [Personality Development in Different Conditions of Socialization]; Vy'davny'chy'j Dim «Slovo»: Kyiv, Ukraine, 2016. (in Ukrainian)

27. Zeer, E.F. Psikhologiya Professiy [Psychology of Professions]; Izdatel'skiy Tsentr «Akademiya»: Moscow, Russia, 2005. (In Russian)

28. Zeer, E.F. Psikhologiya Professional'nogo Razvitiya [Psychology of Professional Development]; Izdatel'skiy tsentr «Akademiya»: Moscow, Russia, 2007. (In Russian)

29. Symanyuk, E.E. Psikhologicheskie Bar'ery Professional'nogo Razvitiya Lichnosti: Praktiko-Orientirovannaya Monografiya [Psychological Barriers to Professional Development of the Individual. Practice-Oriented Monograp]; Moskovskiy psikhologo-sotsial'nyy institut: Moscow, Russia, 2005. (In Russian)

30. Whitaker, C.A. The Technique of Family Therapy. In Changing Sexual Values and the Family; Sholevar, G.P., Ed.; Charles Thomas: Springfield, IL, USA, 1976.

31. Kuzikova, S.B. Samorozvitok osobistosti: Sub'єktnij pidhid [Self-development of the imagination: Subjectiveapproach]. Psihologiya Osobistosti 2013, 1, 77-86. (In Ukrainian)

32. Pavlenko, M.A. Metody i procedury otbora operatorov ASU pri ispol'zovanii intellektual'nyh sistem podderz-hki prinyatiya reshenij [Methods and procedures for the selection of ACS operators using intelligent decision support systems]. Collect. Sci. Work. HUPS 2012, 4, 171-177. (In Russian)

33. Kokun, O.M. Psihologiya Profesijnogo Stanovlennya Suchasnogo Fahivcy [Psychology of Professionalformation of a Modern Specialist]; DP «Informanalit. agentstvo»: Kyiv, Ukraine, 2012; p. 200. (In Ukrainian)

34. Muchinsky, P.M. Psychology Applied to Work: An Introduction to Industrial and Organizational Psychology; Cengage Learning: Boston, MA, USA, 2006; p. 554.

35. Ericsson, K.A.; Charness, N.; Feltovich, P.J.; Hoffman, R.R. The Cambridge Handbook of Expertise and Expert Performance; Cambridge University Press: New York, NY, USA, 2018; p. 918.

36. Brown, T. A Confirmatory Factor Analysis for Applied Research; Guilford Press: New York, NY, USA, 2015 ; p. 462.

37. Kahneman, D.; Klein, G. Conditions for intuitive expertise: A failure to disagree. Am. Psychol. 2009, 64, 515-526. [CrossRef] [PubMed]

38. Evetts, J. Professionalism: Value and ideology. Curr. Sociol. 2013, 61, 778-796. [CrossRef]

39. Gegenfurtner, A.; Lehtinen, E.; Säljö, R. Expertise Differences in the Comprehension of Visualizations: A Meta-Analysis of Eye-Tracking Research in Professional Domains. Educ. Psychol. Rev. 2011, 23, 523-552. [CrossRef]

40. Ayaz, H.; Shewokis, P.A.; Bunce, S.; Izzetoglu, K.; Willems, B.; Onaral, B. Optical brain monitoring for operator training and mental workload assessment. NeuroImage 2012, 59, 36-47. [CrossRef] [PubMed]

41. Dew, N.; Read, S.; Sarasvathy, S.D.; Wiltbank, R. Effectual versus predictive logics in entrepreneurial decision-making: Differences between experts and novices. J. Bus. Ventur. 2009, 24, 287-309. [CrossRef]

42. Kim, J.O.; Mueller, C.W. Factor Analysis: Statistical Methods and Practical Issues; Sage: Newbury Park, CA, USA, 1978 ; p. 88.

43. Wickens, C.D. Engineering Psychology and Human Performance; Psychology Press: New York, NY, USA, $2015 ;$ p. 544.

44. Taylor, S.E. Health psychology: The science and the field. Am. Psychol. 1990, 45, 40-50. [CrossRef] [PubMed]

45. Frank, J.R.; Snell, L.S.; Cate, O.T.; Holmboe, E.S.; Carraccio, C.; Swing, S.R.; Harris, P.; Glasgow, N.J.; Campbell, C.; Dath, D.; et al. Competency-based medical education: Theory to practice. Med Teach. 2010, 32, 638-645. [CrossRef] [PubMed] 